\title{
THE TAX RULINGS - THE CONFLICT BETWEEN THE PRINCIPLE OF LEGALITY AND THE PRINCIPLE OF LEGITIMATE EXPECTATIONS ${ }^{1}$
}

\author{
WOJCIECH MORAWSKI
}

\begin{abstract}
The key research problem is to determine how the development of the interpretation system can be combined with the principle of legality as far as it is referred to the actions of a public authority. This is particularly important in the situation when it appears that the interpretation was incorrect. In Author's opinion the principle of protection legitimate expectations should be given priority when interpretations obtained by taxpayers motivated them to a particular action, while there were no circumstances undermining their confidence in the accuracy of the interpretation. In the Author's opinion, the principle of legitimate expectations should be given priority when interpretations obtained by taxpayers motivated them to a particular action, while there were no circumstances undermining their confidence in the accuracy of the interpretation. seems to be a rational concept. In Poland, however, the problem with protection of the holder of the interpretation does not lie in the defects of the regulations, but in the defects of the practice of their application.
\end{abstract}

\section{Keywords}

Tax; law; ruling; legality; conflict

JEL Classification: D63, H25, K34

Article prepared under a grant funded by the National Science Center (Poland) no. 2016/21/B/HS5/00187 "Acts of interpretation in tax law - between aid, flexibility and disintegration of system of tax law".

2 Professor in Department of Financial Law, Faculty of Law and Administration, Nicholas Copernicus University in Toruń. Contact email: wojciechmorawski.torun@gmail.com. 


\section{Introduction}

Tax interpretations (tax rulings) are an important part of our "tax life". In different forms, they are used in the vast majority of countries around the world. More and more often, the shortcomings of this institution, are highly noticeable. One of the problems discussed by scholars is the issue of compliance of this legal institution with the principles of law. The small part of this problem - resolving the conflict between the principle of legality and the principle of legitimate expectations of the taxpayer - will be the subject of this article.

\section{Poland - Country of Interpretations}

Undoubtedly, Poland is a country, where official interpretations of tax law (tax rulings) play the great role. It is indicated by the number of issued tax rulings. In 2014, tax administration in Poland issued 37.909 tax rulings, and in 2015 - the number of 37,710. It was not until 2016 when there has been a slight decrease in the number of interpretation to 34.151. It should be added, that the Polish authorities of interpretation in 2016 provided 1,712,804 telephone consultations (www.kis.gov.pl). Such action is not considered as a tax ruling, and a person who obtains information by telephone is not entitled to the same protection as the one who receives the ruling. This study omits the issue of these telephone advice. Issuing tax rulings is regulated in detail, by the provisions of the Tax Ordinance Act of 29 August 1997. In addition to individual interpretations, general interpretations are issued by the Minister responsible for public finances (nowadays: Minister of Finance). Unfortunately, they are issued in rather small quantities (only about 10 per year). Taxpayers affected by the general interpretations use similar protection as holders of tax ruling (individual interpretation). The boundary between individual interpretation (private tax ruling) and general interpretations (general tax ruling) in Poland is becoming less and less noticeable. An application for a private tax ruling can also be made by a group of taxpayers who are in the same actual situation, for example, the parties to the same contract (Tax Ordinance Act, Art. 14n). All applicants may benefit from the protection resulting from this interpretation. Formally, however, it is still an individual ruling.

This system is constantly developing, inasmuch, the legislator introduces new specific legal solutions. On 1 January 2017, a new institution appeared - a tax explanation (Tax Ordinance Act, Art. 14i/1a). To create a kind of simplified interpretation, which would also include examples of the interpreted rules usage was the intention of the legislator, which eventuates form the explanation of the project of the bill. Its regulation is laconic, and in practice, there is only one such 
The Tax Rulings - the Conflict Between the Principle of Legality and the Principle...

tax explanation. Also, since 1 January 2017, the new institution named: "fixed interpretation practice" (Tax Ordinance Act, Art. 14n/5-7) has been existing. It does not rely on issuing another type of interpretive act, but on the fact that taxpayer may point to opinions dominating in individual tax rulings which were obtained by other taxpayers in particular tax period (e.g. year in income taxes, month in the VAT) and 12 months of the preceding period. The taxpayer, who relies on a fixed interpretation practice, is treated as if he had an individual tax ruling.

The above-described interpretations are universal in nature - they may refer to the interpretation of all provisions of tax law (with small exceptions). Apart from them, there are also specialized interpretations in Poland. They touch only selected tax regulations. These are primarily (for many years), advance pricing agreements, subject of which, is the acceptance, by the tax authority, of the method of price calculation in a transaction between related business entities (Tax Ordinance Act, Arts. 20a-20r). The securing opinion is a new kind of interpretation. It is a new sort of interpretation of which launching is connected with the appearance (15 July 2016) in the Polish tax law of general anti-avoidance rule (Tax Ordinance Act, Art. 119a-119zf). The resolution, whether the action planned by the taxpayer, will or will not be considered as an abuse of the tax law, is the subject of this interpretation.

In the case of excise duty, there is specific binding excise information. Only the qualifications of the product as an appropriate type of excise product, not the interpretation of all the excise provisions, is the subject of such interpretations. This interpretation solves indirectly the problem of applying excise duty rates and the application of specific regulations to a given type of excise product. Specialized interpretations will not be the main subject of this study. Individual interpretations are essential for the taxpayer in Poland, and this is the main subject that this study will be focused on.

\section{Principle of Legality}

The principle of legality is the foundation of every modern legal system. It is particularly important in tax law when it comes to imposing public burdens on individuals. In tax law, it is the basic guarantee of the taxpayer's rights and the stability of his legal situation. Its roots reach the time of citizens' resistance to the arbitrariness of absolute monarchy. In France, the scholars usually indicate on Art. 14 of the Declaration of Human and Civil Rights of 26 August 1789 as the first manifestation of this principle in the matter of tax law. This provision stipulated, that citizens through their representatives have the right to determine the shape of the tax system (Lamarque, 2009: 286). It is important that originally this principle was a provision protecting the citizen from the arbitrariness of public authority. 
The similar regulation is in many modern constitutions. Nowadays, according to Art. 170/1 of the Constitution of the Kingdom of Belgium: "Any tax for the State may be imposed otherwise than by bill". Article 172 of this Constitution prohibits the granting of tax privileges, tax reliefs, and tax exemptions. It can be granted only by bill. Here appears the second face of this principle. In the context of the so understood principle of legal interpretation does not grant any tax reliefs or tax exemptions, it can only be - in the literal sense of the word "interpretation". In accordance with Art. 217 of the Constitution of Poland "The imposition of taxes, as well as other public imposts, the specification of those subject to the tax and the rates of taxation, as well as the principles for granting tax reliefs and remissions, along with categories of taxpayers exempt from taxation, shall be by means of statute." Article 99 of the Constitution of the Grand Duchy of Luxemburg prohibits any tax privileges. Tax exemption and the tax reduction may be implemented only by law (fr. en vertu de la loi).

The principle of legality in the context of the application of tax rulings turns out to be less approachable to the taxpayer. Results from the fact, that in the circumstances where a taxpayer has the favorable interpretation, but it is considered to be contrary to law, the tax authority will resolve the case based on the law. On one hand it guarantees that the settlement will not be based on the arbitrariness of authority, which might want to impose a higher tax, but on the other hand, it prohibits the authority taking into account that the taxpayer acted in trust to tax ruling. The principle of legality, therefore, stands for the rigor of tax. Its strict application would make the development of the system of tax ruling, impossible.

\section{Principle of Legitimate Expectations}

In the English and French language literature, the principle of legitimate expectation (pl. zasada ochrony uzasadnionych oczekiwań, fr. le principe de confiance légitime) is usually considered in the connection with the principle of legal certainty (Romano, 2002: 331; Michel, 2009: 286).

In French language literature (both French and Belgian), this concept is often cited with the principle of legal security (fr. le principe de la sécurité juridiques), (Forestini, 2003: 55) or with the principle of legitimate trust (le principe de la croyance légitime) (Geelhand, 1995: 57-105, 259-313, 488-523). It should be pointed out that the literature also, sometimes indicates the differences between these principles (Auby, 2007: 473-492). The principle of legitimate expectations consists in the fact that public authorities are obliged to act in accordance to certain standards that they have previously adopted, using their discretionary powers (Romano, 2002: 331). It is worth noticing, that in some countries the above-mentioned idea, 
The Tax Rulings - the Conflict Between the Principle of Legality and the Principle...

is expressed in a slightly different way. In Italian tax law, protection of the rights of the tax ruling's holder is ensured by the principle of good faith, which derives from civil law (Romano, 2002: 337-340). The legal basis of the principle of good faith has been found in various constitutional provisions, such as those guaranteeing economic initiatives, property rights, or of solidarity principle of Art. 2 of the Italian Constitution (Romano, 2002: 339).

The different sources of the rules, do not lead to significant substantive differences. The analysis of solutions adopted in jurisprudence and doctrine in various countries often shows their strict similarities. Actually, each of these concepts comes down to the issue of trust that an individual should give to the state and all activities of its officers. This is a common feature of all concepts and all ideas can be reduced to the principle of trust in the context of the subject of the study. The taxpayer should be able to trust an official opinion about the tax law interpretation expressed by any public authority. This means, that the taxpayer has the right to be sure that the administration's action based on a current way of interpretation of the tax law is a stable situation and the tax authority will, without any justified reasons, not change it. The Belgian Cour de Cassation in its judgment of 27 March 1992, citing the principle of legal certainty, stated: "the right to legal security implies in particular that a citizen must be able to trust that he will not be treated differently than a settled rule of the functioning of administration, it follows from this principle that public services are obliged to honour legitimate expectations that they created in the citizens" (Peeters, 2009: 9).

Therefore, the principle of legitimate expectation will be an argument emphasizing the value of tax ruling, as well as the basis for formulating doctrinal or juridical views and normative solutions aimed at protecting the interests of a taxpayer acting in confidence in such ruling. It must be stipulated that the scope of impact of the principle of legitimate expectation, is of course much wider, than the protection of trust which the taxpayer grant the tax ruling (Gomułowicz, 2011: 95-11).

\section{Resolution of Conflict of Principles - Compromise or Domination?}

The principles of legitimate expectations and principle of legality in the case of tax rulings seem to be clearly contradictory. If we take into account that the principle of legality is usually a constitutional principle, at first glance, one could say that tax ruling are condemned to liquidation. They should be considered as contrary to the law. At most, it would only be to appreciate as legal such rulings which are not contrary to the law. The problem is that the taxpayer needs protection just when 
he applies the interpretation contrary to the law. It would also be fundamentally unfair if the taxpayer who trusted the State, which issued the tax ruling, was not protected in the situation of state's error. It cannot come as a surprise, that there are no (all around the world) ideas for the complete elimination of tax interpretations. It happens, of course, those different actions are taken to examine the negative aspects of their functioning. For example, the European Parliament set up a special committee to investigate the system of tax interpretations in EU countries in the context of harmful tax competition.

In the Report of the European Parliament's Special Committee on Tax Rulings and Other Measures Similar in Nature or Effects (2015/2066 (INI)) - apart from pointing out some irregularities - it was found that broadly interpreted tax rulings "are not intrinsically problematic since they can, as is their original purpose, provide legal certainty for the taxpayer and reduce the financial risk for honest firms in cases where the tax laws or their particular application in certain circumstances are unclear or subject to diverging interpretations, in particular with regard to complex transactions, and thereby avoid future disputes between the taxpayer and the tax authority".

This committee did not propose the prohibition of issuing tax rulings by the Member States of EU, but only suggested taking actions to create "an EU-wide clearing house system, through which tax rulings would be systematically screened by the Commission so as to increase the system's level of certainty, consistency, uniformity, and transparency and check whether such rulings have a harmful effect on the other Member States". Also, in the preamble of Council Directive (EU) 2015/2376 of 8 December 2015 introducing instruments to combat the use of official tax law interpretations in order to avoid taxation (Council Directive (EU) no. 2015/2376) it was pointed out "rulings concerning tax-driven structures have, in certain cases, led to a low level of taxation of artificially high amounts of income in the country issuing, amending or renewing the advance ruling and left artificially low amounts of income to be taxed in any other countries involved. An increase in transparency is therefore urgently required." In the same document, the advantages of this institution were emphasized: "The issuance of advance tax rulings, which facilitate the consistent and transparent application of the law, is common practice, including in the Union. By providing certainty for business, clarification of tax law for taxpayers can encourage investment and compliance with the law and can, therefore, be conducive to the objective of further developing the single market in the Union on the basis of the principles and freedoms underlying the Treaties" (p. 1.1 preambles).

Among other things, experience related to the using of tax rulings as an instrument of harmful tax competition led to greater transparency (Mischo, 2015: 331). 
The Tax Rulings - the Conflict Between the Principle of Legality and the Principle...

Transparency naturally leads to an increase of importance of legalism in the process of launching them. It is the secrecy of the interpretation that allowed countries such as, Luxemburg, to create solutions (favorable for investors, but harmful to the budgets of other countries), that were not provided by the national tax law. In this unlawful way, Luxembourg enabled striking low taxation to illegally transferred income. However, ruling's transparency does not affect the problem of the ruling's holder protection. In this case, unfortunately, it is necessary to decide what is more important: the principle of legality or the principle of legitimate expectations. It is not a revealing statement, that in various countries this conflict is resolved in various ways.

In Belgium, the constitutional principle of legality seems crucial. In the view of the provisions of the Belgian Constitution cited above, the principle of legitimate expectation does not justify invoking an unlawful ruling before a court (Goyens, 2004: 4; Richelle, 2010: 138). The judge or the tax authority cannot in any way, use tax ruling contrary to the law because they are bound by law, not by the ruling. This solution of the conflict between two eponymous principles was originally the result of the judicial activity of the Belgian courts (Morawski, 2012: 389). Later this solution was transposed to the legal regulation. In Belgium, the tax ruling is, in principle, binding on the tax authority, but is not binging when it is contrary to the tax law. This solution seems unreasonable, also in the opinion of Belgian scholars (Vanhulle, 2005: 121). The Belgian legislator, therefore, prefers the principle of legality at the expense of the principle of legitimate expectation. It is very interesting that the tax authorities do not apply this exception to the binding by the ruling. In turn, in the neighboring Netherlands, this conflict was resolved differently. The Netherland's practice stresses the principle of legitimate expectations, although, in this country, there is no provision that would create for tax administration the effect of binding. The tax authorities, however, feel binding by tax rulings (Filipczyk, 2011: 156).

However, even in this country the principle of legitimate expectations is not automatically applied to every interpretation. In particular, two situations should be distinguished. First of all, if the contents of the ruling were obviously contrary to the tax law, then the taxpayer has no ground to enforce the tax ruling against to the tax law. "If it is not obvious that the ruling violates the law, but it is nevertheless favorable to the taxpayer, the tax authorities cannot simply set it aside. The tax authorities could then inform the taxpayer that, in their view, the ruling is not in accordance with tax legislation. The taxpayer is then entitled to a grace period (usually two years) to restructure his operation in the Netherlands. During that grace period, the tax authorities will respect the ruling" (Romano, 2002: 334). The tax authorities may revoke the ruling retroactively only in the situation when taxpayer 
failed to disclose all the relevant fact or intentionally misled the tax authorities (Romano, 2002: 334).

\section{Poland - to Run with Hare and Hunt with the Hounds}

The conflict of the principle of legality and the principles of legitimate expectations in Poland was resolving in various ways. Unfortunately, the only thing that is certain in Polish tax law is its instability. Before going to the presentation of current legal solutions, it is necessary to pay attention to the judgment of the Constitutional Tribunal (K.4/03). It was issued in the period when the legal regulation of tax interpretations was completely different than at present. However, this judgment indirectly shaped the current tax legislation.

In 2004, general interpretations bound the tax authority. The legal nature of individual interpretation was unclear. It is important that the Constitutional Tribunal has recognized that binding the tax authority by a general interpretation is inconsistent with the Constitution of the Republic of Poland. This was justified by the Tribunal, among other things, the fact that the binding of the tax authorities by interpretation blurs the differences between the creation and interpretation of the law.

This judgment influenced the current shape of Polish tax legislation regarding tax interpretations. Nowadays, no Polish tax interpretations are binding. Formally, the tax authority, which decides that the tax interpretation is against the law, must take a decision in accordance with the law, and therefore, contrary to the interpretation. This does not mean that the taxpayer cannot trust the ruling. Acting in accordance with the interpretation (both individual and general) before its changing must not be detrimental to the taxpayer. If the interpretation concerned events prior to its issue, the taxpayer is exempt from the obligation to pay default interest but is not exempt from paying the tax (Art. 14k Tax Ordinance Act).

If the interpretation concerned actions planned by the taxpayer, then, the taxpayer is entitled to an exemption from the duty to pay the tax in the scope resulting from the event being the subject of the interpretation. This exemption is granted on condition that the tax obligation was not performed properly due to the application of an interpretation that was changed, or which was not taken into account in the resolution of the tax case, and tax consequences connected with the event corresponding to the facts forming the subject of the interpretation occurred after the publication of the general interpretation, or after the delivery of the individual interpretation (Tax Ordinance Act, Art. 14m/1). However, the exemption is applied only at the request of the taxpayer. He must apply to the tax authority in this matter. 
The Tax Rulings - the Conflict Between the Principle of Legality and the Principle...

Similarly, to other countries, Polish law also provides taxpayers with a time of grace. This is a period after changing the interpretation, in which one may benefit from the exemption. Due to the fact, that the reason for the changing interpretation is based on the tax authority's recognition that the interpretation is unlawful, it means that Polish law indirectly accepts the using the interpretation contrary to the law.

The exemption referred shall include:

1) in the case of annual tax settlements - the period until the end of the tax year in which the changed general interpretation was published, the changed individual interpretation was delivered, or a copy of the administrative court's judgment reversing the individual interpretation with a statement of its validity was delivered to the tax authority,

2) in the case of quarterly tax settlements - the period until the end of the quarter in which the changed general interpretation was published, the changed individual interpretation was delivered, or a copy of administrative court's judgment reversing the individual interpretation with statement of its validity was delivered to the tax authority, as well as the following quarter,

3 ) in the case of monthly tax settlements - the period until the end of the month in which the changed general interpretation was published, the changed individual interpretation was delivered, or a copy of administrative court's judgment reversing the individual interpretation with a statement of its validity was delivered to the tax authority, as well as the following month (Tax Ordinance Act, Art. 14m/2).

Polish tax legislation is characterized in this matter by automatism. The reasons for the defectiveness of interpretation are not taken into account at all. As a result, the interest of the ruling's holder is also protected, even though, the taxpayer was fully aware of the obvious defectiveness of the interpretation. This raises the doubt, whether the Polish legislation has gone too far to protect the trust of the taxpayer. A positive aspect of this solution is to minimize potential conflicts related to determining whether the error of the tax authority could be detected by the taxpayer, or not.

However, there are some "traces" of legalism in the Polish legislation. The mechanism of protection is based on granting the exemption to the taxpayer, not on the binding effect of the interpretation. Formally, the tax authorities calculate the tax on the basis of the law and only then will apply for the tax exemption. This is a solution other than the one applicable in the Netherlands. The application of the principle of protection legitimate expectations in the Netherlands is somewhat more flexible, depending on, whether the interpretation was obviously incorrect, or not. In this way, the problems related to the taxpayers who point out to obviously 
incorrect interpretation (issued as a result of the incompetence of the public officials), are omitted. The Dutch practice shows, that the principle of protection legitimate expectations does not necessarily lead to the full binding of the tax authorities by the interpretation. Very good substantive preparation of the Dutch tax authorities and the will to cooperate with taxpayers (more on the functioning of the tax administration in the Netherlands-Alink, 2009) result that the ruling system in the Netherlands functions relatively well.

\section{Conclusions}

The ways of the resolving the conflict between the principles of legality and the principle of legitimate expectations are of course different in various countries. In Belgium, theoretically, an illegal interpretation does not protect the holder. However, in practice, this is not a problem for taxpayers, because the tax authorities act in accordance with interpretations. There is no clear legal regulation in the Netherlands, but in practice, the taxpayer is fully protected when he acts in confidence in interpretation, with exception of the situation when the ruling is obviously incorrect.

The principle of legality wins formally in Poland, but a deeper analysis of the tax legislation leads to the conclusion that the taxpayer is fully protected, more than in Netherland. This protection is, maybe, excessive. When it appears that the interpretation was incorrect, granting taxpayer protection or compensation related to the issuance of an incorrect interpretation seems to be in contradiction with the principle of legality, because it leads to situations in which law regulations will not be applied to the taxpayer. On the other hand, one can not deny that the protection of confidence of the taxpayer to the authority which issued the interpretation has also its essential significance. It is, therefore, necessary to indicate the directives helpful in resolving the conflict of principles. It is not, of course, the matter of a "simple" resolving, which principle is more valid, because in different contexts it seems reasonable to give priority sometimes to one of them, sometimes to the other.

In the Author's opinion, the principle of legitimate expectations should be given priority when interpretations obtained by taxpayers motivated them to a particular action, while there were no circumstances undermining their confidence in the accuracy of the interpretation. seems to be a rational concept. In Poland, however, the problem with protection of the holder of the interpretation does not lie in the defects of the regulations, but in the defects of the practice of their application. In recent years, very often the tax authorities search for small and irrelevant differences between the content of the application for issuing the interpretation and the future business activity of the holder. In practice, this destroys the sense of security of 
The Tax Rulings - the Conflict Between the Principle of Legality and the Principle...

taxpayers. The practice of the operation of tax authorities is more important than the regulations.

\section{References}

Alink, A., van Kommer, V.: The Dutch Approach, Description of the Dutch Tax and Customs Administration, Amsterdam: BFD Publications BV, 2009.

Auby, J.B, Dero-Bugny, D.: Les principes de sécurité uridiques et de confiance légitime (The principles of legal certainty and legitimate expectations), in: Auby, J.B, Dutheil de la Rochère, J. (eds.): Droit administratif européen (European administration law), Bruxelles: Bruylant, 2007.

Ferreira, E., Theurer, M.: Report of the Special Committee on Tax Ruling and Other Mesures Similar or Effect no. 2015/2066(INI) (2015).

Filipczyk, H.: Indywidualne interpretacje prawa podatkowego (Individual tax intepretations), Warszawa: Oficyna Prawa Polskiego, 2011.

Forestini R.: Les accords avec l'administration fiscal (Agreements with the tax authorities), Bruxelles: Larcier Group, 2003.

Geelhand, N.: Le principe de la croyance légitime en droit administratif et en droit fiscal (The principle of legitimate belief in administrative law and tax law), Revue critique de jurisprudence belge (Critical review of Belgian case law) no. 3 (1995).

Gomułowicz A., Małecki J., Podatki i prawo podatkowe (Taxes and tax law), Warszawa: LexisNexis, 2011.

Lamarque, J., Négrin, O., Ayrault, L.: Droit fiscal general (General tax law), Paris: LexisNexis, 2009.

Michel, V.: Brève observations sur l'application des principes de sécurité juridique et de confiance légitime (Brief comments on the application of the principles of legal certainty and legitimate expectations), La gazette du Palais no. 1 (2009).

Mischo, P., Kerger, F.: The New Luxembourg Tax Ruling Procedure, European Taxation no. 7 (2015).

Morawski, W.: Interpretacje prawa podatkowego i celnego - stabilność i zmiana (Tax and custom law interpretation - stability and change), Warszawa: Wolters Kluwer, 2012.

Richelle, I.: Belgium, in: Lang, M., Pistone, P., Schuch, J., Staringer, C. (eds.): Procedural Rules In Tax Law In the Context of European Union and Domestic Law, Oxford: Kluwer Law International, 2010.

Romano, C.: Advance Tax Rulings and Principles of Law Towards a European Tax Rulings System? Amsterdam: International Bureau of Fiscal Documentation, 2002.

Vanhulle, V.: The Belgian Advance Ruling Procedure: Recent Experience and Greater Efficiency and Flexibility from 2015, European Taxation, no. 3 (2015).

Goyens de Heusch F.: La pratique du ruling fiscal en Belgique (The practice of the tax ruling in Belgium). www.goyens.eu. 
Peeters, B.: La relation entre le principe de sécurité juridique et le principe de l'égalité: un processus d'Echternach? (The relationship between the principle of legal certainty and the principle of equality: an Echternach process?), 2009. www.tiberghien.com.

EU: Council Directive (EU) 2015/2376 of 8 December 2015 amending Directive 2011/16/EU as regards mandatory automatic exchange of information in the field of taxation.

PL: Tax Ordinance Act of 29 August 1997, as amended.

PL: Constitutional Tribunal: K.4/03. 